\section{A SCIENTIFIC RESEARCH ASSOCIATION.}

$\mathrm{I}$ the spring of this year steps were taken at Cambridge to form a scientific research association, and a provisional executive committee was appointed to bring the matter before a limited number of selected representatives of the various branches of science throughout the country. The aims of the association were defined as follows :-

(1) To be prepared to offer advice and information to those who wish to devote themselves to scientific research.

(2) To be prepared to give advice to bodies administering public funds for research as to the most useful ways in which such funds could be applied.

(3) To impress upon the attention of the public the importance of scientific research, and thus to promote a wider understanding of the fundamental value of scientific method.

(4) To consider the possibility of organising a scheme of permanent national endowment so as to afford opportunities for young and promising students to establish themselves in research work, and to secure to the ablest of these the possibility of a career devoted mainly to the continued pursuit of scientific investigation.

Widespread and representative support was obtained for the project, seventy fellows of the Royal Society being among those who signified their adhesion to these aims, and this has encouraged the provisional committee to proceed with the vork of drafting an outline of the proposed constitution and organisation of the association. This draft, with an explanatory statement of the aims of the association and a first list of supporters, has now been issued in a circular which is abridged below. Though the association had its origin in Cambridge, its activities are, of course, not intended to be limited to Cambridge, but to be national in scope, membership being open to all who have published research or are engaged in research for publication, and associate-membership to all who, without being engaged in research, have its interests at heart. $\Lambda$ general meeting will be called in London as soon as possible, to which rules and constitution will be submitted, and at which a governing body and officers will be appointed who will fix the details of organisation. The acting secretary is Mr. A. G. Tansley, F.R.S., Grantchester, Cambridge, to which address applications for membership or for further particulars of the association should be sent.

It is believed that the time is ripe for the formation of a scientific research association to watch over and promote the interests of research in pure science in this country. While applied sceince has recently received a notable stimulus owing to the urgent demands of the war, there is a real danger that the interests of pure science, in spite of recent and very explicit public recognition, may remain neglected. In view of the large projects of reconstruction now occupying the best minds, it seems particularly opportune for men of science to make a concerted effort both to improve the efficiency of their own contribution to national life and to bring home to the mind of the nation the vital importance of science and the scientific method in all departments of national life.

In the first place, it is believed that science requires not only larger endowments, but also more co-ordinated and informed allocation of those endowments than is provided by any existing machinery. It is thought that the best way to construct really adequate machinery is to provide a comprehensive internal system of intelligence as to the research that is actually being done in the various branches of science and of new research as it is projected. Such a system would serve a double furction. It would increase the use of existings facilities by putting qualified workers into touch with institutions where the most satisfactory conditions for carrying out their researches already exist, and reciprocally by suggesting to institutions and departments the names of suitable workers. It would also quickly bring to light the deficiencies in existing facilities and enable suggestions to be made for their improvement and increase. Work of this kind is, of course, already done privately and by various bodies, but it is more or less sporadic, casual, and unco-ordinated. It is believed that systematic organisation of such intelligence work would be of great value in facilitating and stimulating the carrying out of research.

It is also believed that the best-indeed, the only completely efficient-method of creating the machinery required is to associate together the whole body of men of science on a democratic basis. It is only by such association that really full information can be obtained and impartially sifted.

The governing body of the association would serve as a link between the proposed intelligence organisation and the Government Departments and other public bodies controlling funds available for the endowment of research, acting as an organ of intelligence as to the funds required. There have already been created, under the auspices of the Department of Scientific and Industrial Research, a number of industrial research associations which will keep the Depart ment informed of the needs and prosress of industrial research, as well as themselves carrying on research. Making allowance for the difference of conditions, the Scientific Research Association would aim at performing a somewhat similar function in regard to research in pure science, thoush it would not of course, itself undertake research.

The association would necessarily acquire a unique body of information as to the existing situation in regard to research, and would thus be in an exceptionally favourable position for suggesting new and nromising lines of development. A conspicuous feature of much recent research has been the development of co-operation, not only between different workers in the same branch of science who undertake joint work on problems beyond the porver of single workers to cope with, but also between workers in different departments who co-operate in an attack upon border-line problems which require for their solution the contributions of men trained in more than one branch of science. The comprehensive organisation of the association should render it specially capable of facilitating or even of initiating this kind of fruitful co-operation.

No interference with the work of any existing body is contemplated. The association would act as a co-ordinating agency, and would endeavour to co-operate intimately with existing scientific bodies and to assist all efforts of a similar kind that are at present being made. Thus the Medical Research Committee at present attached to the National Health Insurance Department, in addition to initiating and carrving out research on its own account, also performs similar work in regard to medical research. The Scientific Research Association would hope to co-operate with that Committee in regard to research having a direct or indirect bearing on medical problems, rendering the Committee any assistance that might be possible. It has been suggested that No. $256 \mathrm{I}$, VOL. IO2] 
specialist societies representing practically the whole of the research workers in their respective subjects might in some cases be able and willing to carry out the functions contemplated for the subject committees of the association. In such cases, to avoid duplication of organisation, it might perhaps be arranged for the corresponding subject committees to be dispensed with and for the societies in question to have the necessary representation on the association.

But it is felt that the aims of the association should go beyond the better co-ordination of existing worls and endowments. There is no doubt that if the national life is to be increasingly vitalised by scientific research and the development of the scientific habit of mind, the ranks of scientific workers must be much more amply reinforced from the best human material. In order to secure such a result it is essential that an assured career should be open to the competent research worker. It is therefore proposed to formulate an extensive scheme of State endowment of research which would afford opportunities for young and promising students to establish themselves in research work and to secure to the ablest of these the opportunity of a career devoted mainly to the continued pursuit of scientific investigation. It is not intended to advocate action which would lead to the separation of research and teaching functions, which are often fruitfully combined in existing circumstances, but rather to secure conditions in which those who are best fitted for research mav devote themselves mainly or wholly to research without anxiety.

Finally, it is thought that the association might usefully play a leading part in impressing upon the attention of the public by carefully organised propaganda along definite lines the importance of scientific research in all its aspects, and especially the fundamental value of scientific method in everv department of national life and the special claims of pure science to national support.

The proposed organisation and functions include :(i) Information, Intelligence, and Advice.-(a) Special, dcaling with the needs of and facilities for research in the different branches of science. Organ : Subject committees and secretaries, intermediary between individuals and institutions. These subject committees and their secretaries would be the most important part of the organisation so far as detailed intelligence work was concerned. They would form a sort of internal nervous system of research in the different subjects, and the threads would be gathered up by the council when it was a question of the need for fresh endowments. The subject committees would not be limited in membership, most of their work being done by correspondence, and would be made really representative of the whole of the research in each subject.

(b) General intelligence and advisory functions. Organ : Council, General Purposes Committee, General Secretary, intermediary between Government and other bodies controlling funds available for research on one hand, and institutions and individuals carrying on research on the other, partly through the agency of the subject committees.

(ii) (c) Propaganda.-Impressing upon public attention the value and importance of scientific method and scientific research in every department of life. Organ: Propaganda Committee and Propaganda Secretary.

(iii) (d) Formulation of Scheme of State Endoroment of Research. Organ: General Purposes Committee and Council.

The proposed working of the organisation here outlined is described in the circular referred to.

NO. 256 I, VOL. IO 2 ]

\section{SCIENCE AND THE FUTURE. ${ }^{1}$}

A MATTER which we now see constantly referred to, in every newspaper and by many public speakers, is what is known as reconstruction-that is to say, the putting of our affairs in order after the finish of the war. Now, undoubtedly the war has been responsible for an enormous amount of destruction of capital; but when estimates are given, as they constantly are given, of the percentage of loss in Belgium, France, Italy, Serbia, and other countries, it is not usually borne in mind that capital does not merely consist of gold and silver, of bricks and mortar, of furniture and fitments, or even of railways, steamships, and machinery-mostly things that in process of time fall into decay-that the main capital of the modern world does not consist of the concrete constructions of labour or of material things at all, but of scientific knowledge. If we could imagine such a catastrophe as destruction on the scale that has recently taken place in the fighting zones spread over the whole civilised world, so that nothing was left anywhere at all of the material handiwork of the past few hundreds of years, this would not necessarily mean the relapse of mankind in general to the savage state of our prehistoric ancestors, who lived before the accumulation of our present priceless scientific knowledge had even begun. That this is so we see clearly from the lessons of the past. For thousands of years the manual labourer has been at work, and untold have been the products of his toil. How many of these products, however, have come down to the present day? Where are now the splendid constructions, the magnificent buildings, the costly and varied manufactures of ancient Babylon, Egrnt. Greece, and Rome? A few scattered frasments of a purely antiquarian interest, but of no utilitarian value, are all that are left. "The greater portion have entirely disappeared. But not so the products of the ancient mind. These, to a large extent, still endure. For all our industries, all our arts and crafts, and all our sciences have their roots in the distant past. Some knowledge of importance may, in the crash of empires and the great social convulsions that have taken place, have been lost or forgotten, but comparatively not much; while, owing to the invention of printing, and the consequent easy multiplication of records, this is never likely to happen again-at anv rate, on a considerable scale.

Thus to reconstruct the material things now temporarily destroyed will take only a very small fraction of the labour that had to be expended, or of the centuries of time that had to pass, while, by slow degrees and arduous effort, man learnt how to bring all these things about. For the mere construction of the material paraphernalia of civilisation is in value as nothing to the knowledge of how to construct them. Taking this into consideration, we recognise the fallacy of the doctrine that all wealth is due to manual labour, and we see how little of the capital of the world is really due to mere handiwork, however skilled, and how much to the mental efforts of exceptional men. who through countless generations, by their investigations, discoveries, and inventions, have rendered possible all our wonderful possessions. When, therefore, we compile estimates of the losses due to the war, let us not forget that our greatest asset, the vast store of knowledge that Science has gathered together for us the heirs of all the ages, is still intact. It is a store that has slowly been accumulating ever since the beginning of the

1 Abridged from the inangural address delivered before the Royal Society of Arts on November 20 by the chairman of the council, A. A. Camphell Swinton, F.R.S 